\title{
SIZE AT MATURITY AND SPAWNING PERIODICITY OF THE MUD CRAB SCYLLA SERRATA (FORSKAL) IN THE NEGOMBO ESTUARY
}

\section{S. C. JAYAMANNA}

National Aquatic Resources Agency, Colombo 15.

AND

\section{J. JINADASA*}

Department of Zoology, University of Sri Jayewardenepura, Nugegoda.

(Date of receipt : 11 August 1992)

(Date of acceptance : 16 April 1993)

\begin{abstract}
Some aspects of reproductive biology of the mud crab, Scylla serrata in the Negombo estuary were studied by screening bi-weekly samples over a period of one year. The study revealed that the size of the female crab at first maturity was 12 $\mathrm{cm}$ and the estimated pre-spawning and post-spawning fecundities were around 3 and 1.5 million respectively. The ova mature at the size of about $300 \mu \mathrm{m}$ and are found in three batches indicating a partial spawning behaviour. Spawning occurs in two seasons, April and August. The sex ratio was uneven in most size groups and in most months of the year. About $85 \%$ of the commercial catches comprise inmature females.
\end{abstract}

Key words : Mud crab, spawning periodicities

\section{INTRODUCTION}

The mud crab Scylla Serrata (Forskal) is an important constituent of commercial fishery in Sri Lanka. The average annual export of mud crabs during the past five years amounted to 484 metric tons and earned 36 million rupees per annum. However information on its fishery, and particularly on its reproductive characteristics are very scant. Studies have been done in other countries on the reproductive biology of the species but mostly under different conditions.

Duplessis ${ }^{1}$ reported that mud crabs reach maturity at a size of $131-141 \mathrm{~mm}$ carapace width; and that they extrude batches of ova without mating between ovulations. Lavina ${ }^{2}$ observed the courtship and mating behavior of Scylla serrata in captivity and reported that mating took place for 2-7 days. In Australia, mud crabs mated in mid-spring and late autumn. ${ }^{3}$ Fecundity of Scylla serrata was reported to be 1-3 million eggs. ${ }^{4,5}$ Migration of females to sea after mating for spawning has been reported. ${ }^{5,6}$ Spawning begins in spring reaching a peak in early summer and ends during autumn in sub-tropical regions whereas it reaches a peak between May to September in the tropics.

\footnotetext{
To whom correspondence should be addressed.
} 
Effect of eye stalk ablation on the gonadal maturation of Scylla serrata was tested ${ }^{7}$ and reported that the extirpation of eye induced the groth of testis in size and weight. Sex ratio of the mud crab was always reported to be even. ${ }^{3,8}$

The published information on Scylla serrata in Sri Lanka is limited to two studies carried out by Raphael ${ }^{9}$ on aquaculture potential of the mud crab and the host-parasite relationship of Scylla serrata and Octolasmis cor by Arudpragasam ${ }^{10}$ in 1967. The present paper reports observations on the size at maturity and spawning periodicity of mud crab Scylla serrata in a tropical estuary, Negombo in Sri Lanka.

\section{METHODS AND MATERIALS}

Bi-weekly samples of female Scylla serrata collected from the Negombo estuary were studied for a period of one year beginning January 1989. The samples to study gonads were selected to represent crabs of all sizes in the market making a sample of 50 or the entire catch where the catch was less than 50 . The samples collected on each sampling day were transported live to the laboratory for further study. Carapace width (the maximum width between antero-lataral spines) of all the crabs in the market was measured to the nearest $\mathrm{mm}$ with Vernier calliper and the weights were measured in a Sartorius balance with a precision of two decimal points, prior to being dissected. Crabs were dissected in live condition since the ovaries tend to disintegrate once the crabs are dead. After the dissection the different maturity stages of the ovary were determined by the scale used for Cancer irroratus by Bigford. ${ }^{11}$

After the stages of maturity were determined the ovaris were excised and fixed in Gilson fluid. The fixed ovaries used for studies on fecundity and ova diameter frequency.

Two types of fecundities were estimated. The first was the pre-spawning fecundity in which the number of ova in the matured ovary was estimated. For the post-spawning fecundity the spawned or shed ova found attached to the abdominal appendages (ova of oviferous females) were counted. To prepare specimens for both types of ova counting, the ovaries were mopped in a blotting paper to remove moisture, then 5 pieces, each weighing approximately $0.5 \mathrm{~g}$ were cut from the middle region of the ovary and were weighed to the nearest milligram using a Sartorius balance. Thereafter each piece containing separated eggs were taken out, diluted in $100 \mathrm{ml}$ water and subsamples each of $1 \mathrm{ml}$ were taken out with a stempel pipette for counting the ova under a magnifying glass. These counts were to estimate the fecundity.

Ovaries of crabs of the six different stages of maturity ; immature, developing, mature, spawning, post-spawning and spent were used for the ova diameter frequencey studies. Portions weighing about $0.5 \mathrm{~g}$ comprising anterior, middle and 
posterior parts of the ovary were mixed with water and were observed under microscope. The ova diameters were measured in the first one hunderd eggs viewed by using an ocular micrometer scale at $0.5 \mathrm{~mm}$ magnification to each micrometer division.

The size at first maturity was determined based on observations made on female crabs of different sizes ranging from $4.0 \mathrm{~cm}-18.00 \mathrm{~cm}$ carapace width. The crabs were grouped into $1 \mathrm{~cm}$ classes and the percentage of mature crabs in each class was calculated. In calculating the percentage of mature females, the female crabs of maturity stages I and II were taken as immature and stage III and above as mature. The mature ovaries were bright yellow to orange in colour. Males were not chosen for this study because of the difficulties in identifying their stage of maturity.

The distribution of crabs according to sex in commercial catches during the period from January 1985 - December 1987 was statistically tested using the chi-square test. The chi-square values were calculated for each length group $(1 \mathrm{~cm}$ size group) assuming a sex ratio of $1: 1$ (Table 1.).

Table 1: Seasonal variation in sex ratio. of crabs in commercial catches in the Negombo Estuary during the three years, 1985, 1986 and 1987.

\begin{tabular}{|l|c|c|c|c|c|c|}
\hline Year & \multicolumn{2}{|c|}{1985} & \multicolumn{2}{c|}{1986} & \multicolumn{2}{c|}{1987} \\
\hline Month & Male & Female & Male & Female & Male & Female \\
\hline January & 48 & 74 & 1071 & 557 & 425 & 764 \\
\hline February & 189 & 326 & 865 & 727 & 172 & 287 \\
\hline March & 235 & 323 & 623 & 544 & 234 & 349 \\
\hline April & 195 & 406 & 284 & 336 & 103 & 179 \\
\hline May & 200 & 300 & 175 & 224 & 242 & 338 \\
\hline June & 187 & 213 & 296 & 345 & 389 & 424 \\
\hline July & 262 & 336 & 446 & 527 & 258 & 335 \\
\hline August & 330 & 413 & 439 & 661 & 264 & 483 \\
\hline September & 341 & 200 & 630 & 799 & 423 & 542 \\
\hline October & 562 & 354 & 596 & 708 & 267 & 488 \\
\hline November & 1125 & 541 & 179 & 391 & 527 & 921 \\
\hline December & 954 & 564 & 374 & 723 & 386 & 596 \\
\hline
\end{tabular}

Significant at the level $P<0.05$.

\section{RESULTS}

The percentage occurrence of mature females of Scylla serrata in the samples indicated that all the crabs below $10 \mathrm{~cm}$ carapace width were immature while all those 


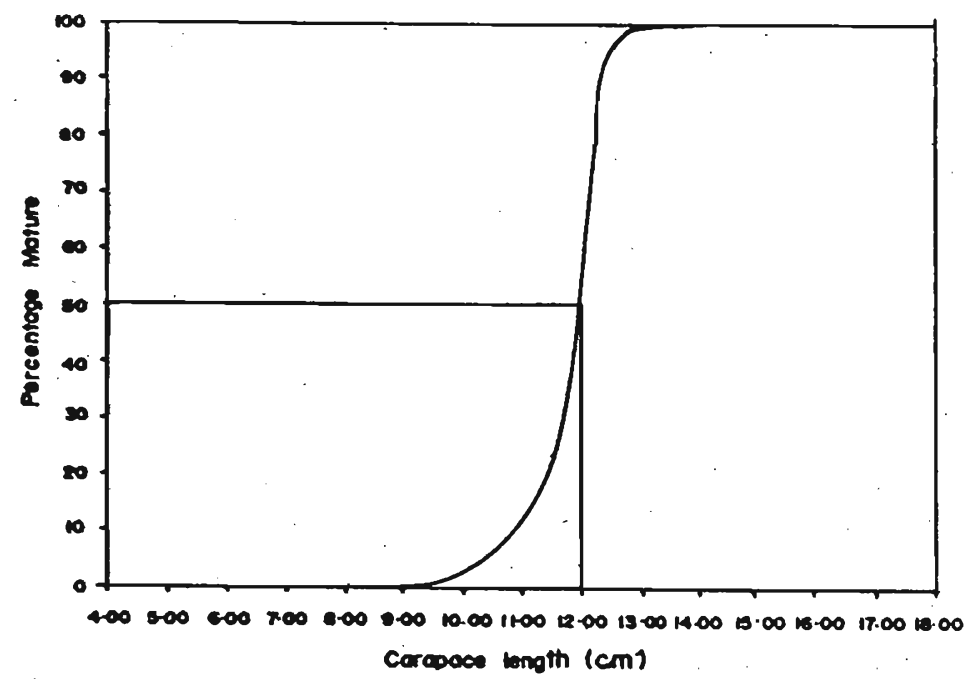

Figure 1: The relationship between the carapace length and percentage maturity of Scylla serrata in the Negombo Estuary. ( $=17535)$

above $13 \mathrm{~cm}$ were mature (Figure 1). The $50 \%$ maturity was obtained at $12 \mathrm{~cm}$ carapace width as calculated from the curve.

The pre-spawning fecundity varied from $1.76 \times 10^{6}$ to $3.5 \times 10^{6}$ while the post-spawning fecundity varied from $1.28 \times 10^{6}$ to $1.84 \times 10^{6}$. The relationship between post-spawning fecundity (Figure 2) and the carapace width shows that the post-spawning fecundity is linearly correlated $(r=0.89)$ to the carapace width and the estimated regression equation is

$$
\mathrm{F}=-185449+146795 \mathrm{CW} \quad(\mathrm{r}=0.89)
$$

No correlation was observed between pre-spawning fecundity and the carapace width.

The percentage distribution of maturity stages indicated that there were more immature females during the periods June - July and November - December (Figure 3-a). Higher percentages of developing crabs are observed in January, March and August (Figure 3-b). Two peaks are demonstrated in the percentage occurrence of mature female crabs during the periods January - March and August - September (Figure 3-c). The maturity stage iv (Gravid) exibits two peaks (Figure 3-d), first peak in April and the second in August. In spent females the peaks were oberved in May and September (Figure 3-e). 


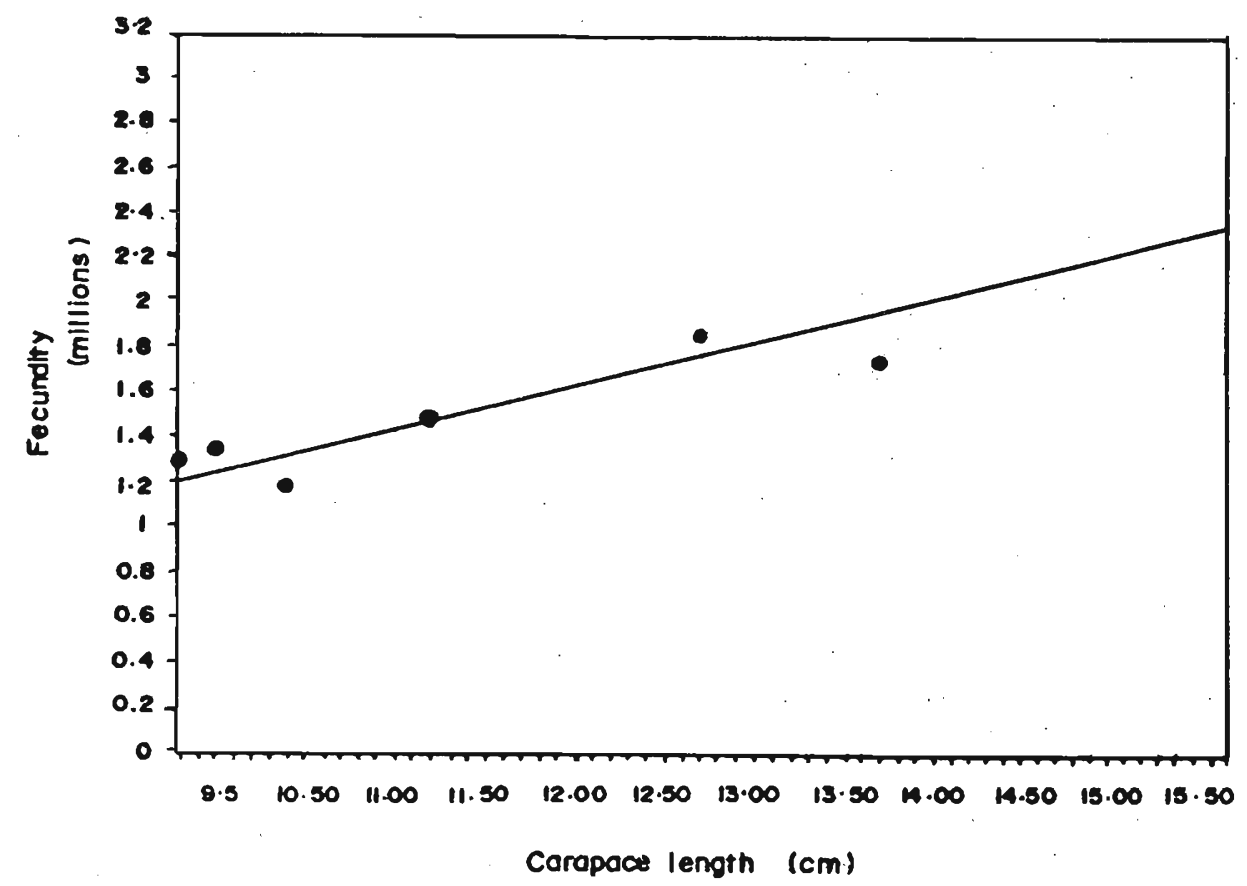

Figure 2: The relationship between the carapace length and the post-spawning fecundity of Scylla serrata in the Negombo Estuary.

Ova diameter frequencies were studied in six different stages of maturity. The ova diameter of stage 1 ovaries ranged from $20 \mu \mathrm{m}-70 \mu \mathrm{m}$ with mode lying between the range of $50-70 \mu \mathrm{m}$ (Figure 4-a). The developing ovaries (stage II) contained ova varing from $140 \mu \mathrm{m}-150 \mu \mathrm{m}$. The ova diameter of stage III (mature) varied from $110 \mu \mathrm{m}-220 \mu \mathrm{m}$ and indicated that all the ova do not mature at the same time. The mature ova ranged from $180 \mu \mathrm{m}-230 \mu \mathrm{m}$ in diameter and is represented by the peak appear in the stage iv. The fourth maturity stage (gravid) shows three batches of ova (Figure 4-d). The first group between $240-270 \mu \mathrm{m}$, second group $270-290 \mu \mathrm{m}$, and the third between $290-320 \mu \mathrm{m}$. The third batch might be the ripe ova which is about to be shed. The fifth stage consists of two types of ova viz., the ova in the ovary and the shed ova still attached to the abdominal appendages. The ova in the ovary shows and irregular pattern within the size range $290-400 \mu \mathrm{m}$ (Figure 4e). The shed ova shows a single peak at $380 \mu \mathrm{m}$ and this lies between $340-400 \mu \mathrm{m}$ (Figure 4e). The sixth stage is the spent stage which comprises a single batch of immature ova between the size range $50-100 \mu \mathrm{m}$ (Figure 4f).

The sex ratio showed an uneven variation in the three years of study (Table 1). In the first year the males and females were evenly distributed in smallar and larger 


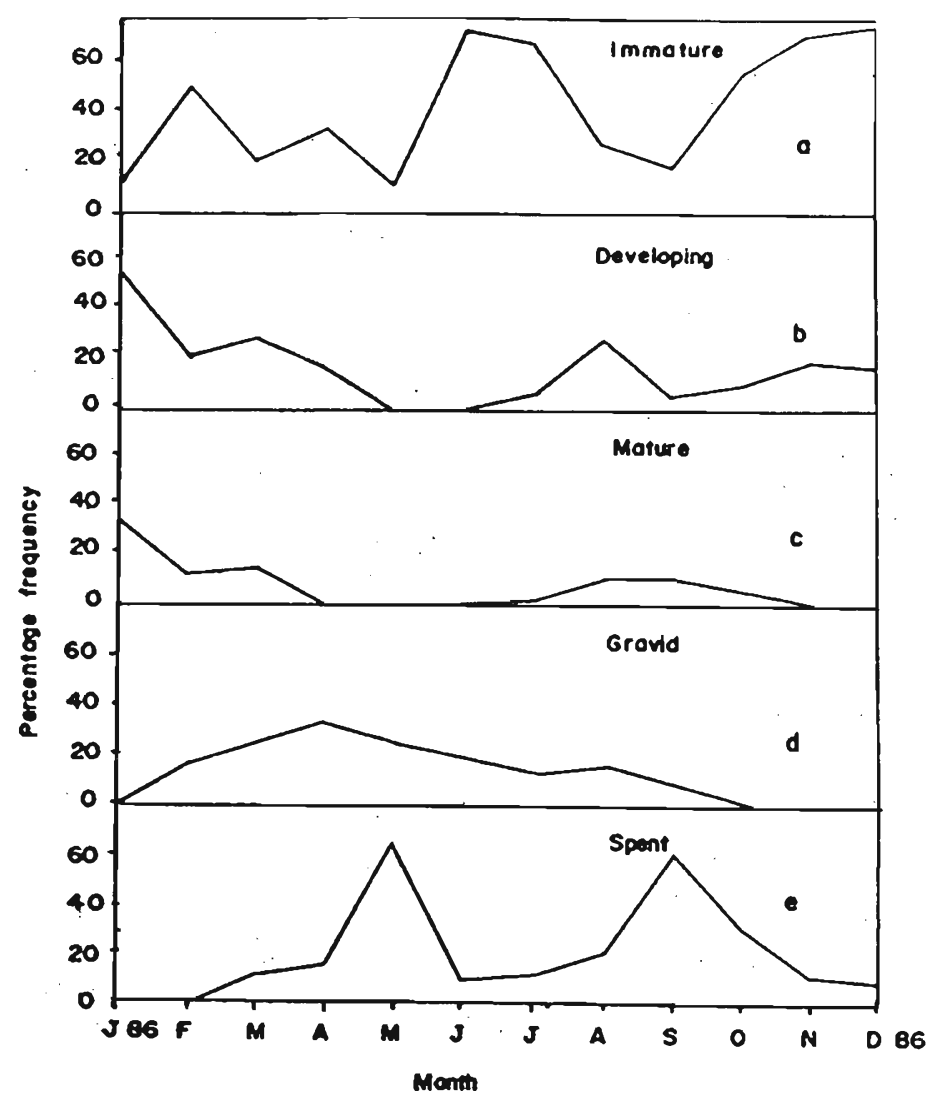

Figure 3: Seasonal variations in the percentage frequency occurrence of different maturity stages of Scyla serrata (a,b,c,d,e) in the Negombo Lagoon. ( $n$ values : $a=127, b=226, c=98, d=294$, $e=$ (14.)

length groups. However, the chi-square value was significant in favour of males in the length range $7.5-9.5 \mathrm{~cm}$. In the second year males and females were even in much larger groups extending upto $9.5 \mathrm{~cm}$ and also in the two largest groups 17.5 and $18.5 \mathrm{~cm}$. The chi-square values were significant in favour of females in the length range 13.5 - $16.5 \mathrm{~cm}$. However, in the length groups 6.5 and $7.5 \mathrm{~cm}$, the chi-square significance was in favour of males. In the third year, female significance was (6.5 $15.5 \mathrm{~cm}$ ) demonstrated in a much broader range. 


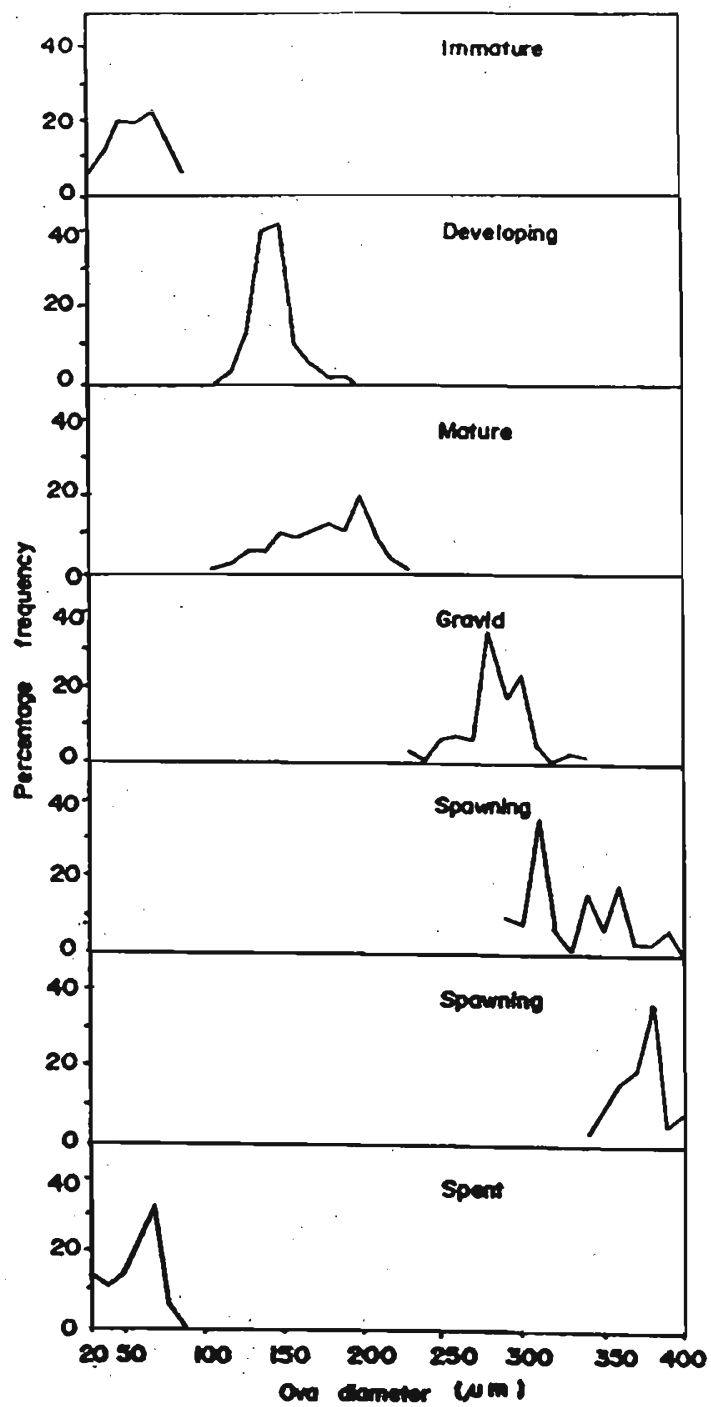

Figure 4: Ova diameter frequencies of Scylla serrata at different maturity stages in the Negombo Estuary. (n values: immalure $=17$, developing $=22$, mature $=10$, gravid $=29$, spawning $=31,27$, spent $=11$ ) 
The seasonal variation in the occurrence of males and females in commercial catches indicated that the males : female ratio is significant in favour of females in most months (Table 2). However, in the month of June in all three years the males and females were even in the catch.

Table 2: Sex ratio in different size groups of Scylla serrata in commercial catches in the Negombo Estuary during the three years, 1985, 1986 and 1987.

\begin{tabular}{|c|c|c|c|r|r|r|}
\hline Year & \multicolumn{2}{|c|}{1985} & \multicolumn{2}{c|}{1986} & \multicolumn{2}{c|}{1987} \\
\hline $\begin{array}{c}\text { Midlength } \\
(\mathrm{cm})\end{array}$ & Male & Female & Male & Female & Male & Female \\
\hline 4.5 & 20 & 21 & 4 & 9 & 2 & 3 \\
\hline 5.5 & 51 & 50 & 44 & 23 & 34 & 69 \\
\hline 6.5 & 266 & 210 & 287 & 214 & 226 & 359 \\
\hline 7.5 & 734 & 597 & 751 & 692 & 531 & 760 \\
\hline 8.5 & 1286 & 924 & 1301 & 1236 & 904 & 1194 \\
\hline 9.5 & 938 & 766 & 1292 & 1280 & 785 & 1207 \\
\hline 10.5 & 566 & 592 & 1004 & 1176 & 501 & 837 \\
\hline 11.5 & 413 & 395 & 686 & 851 & 326 & 570 \\
\hline 12.5 & 193 & 210 & 342 & 631 & 181 & 368 \\
\hline 13.5 & 78 & 84 & 147 & 245 & 93 & 146 \\
\hline 14.5 & 32 & 47 & 73 & 129 & 54 & 94 \\
\hline 15.5 & 37 & 30 & 24 & 63 & 25 & 47 \\
\hline 16.5 & 17 & 17 & 17 & 44 & 19 & 32 \\
\hline 17.5 & 7 & 8 & 6 & 10 & 6 & 8 \\
\hline 18.5 & 3 & 4 & 2 & 2 & 3 & 6 \\
\hline
\end{tabular}

Significant at the level $P<0.05$.

The width frequency distribution of females of mud crabs obtained from the market collection for the year 1988 shows that there are about $85 \%$ immature crabs in the stock (Figure 5).

\section{DISCUSSION}

Around $50 \%$ of the female mud crabs in the Negombo estuary appear to reach maturity at the size of $12 \mathrm{~cm}$ in carapace length. This is comparable to observations made in South Africa (13-14 cm $)^{2}$ and Phillppines $(8.5-11.1,10-12.5 \mathrm{~cm})^{12,13,14} \mathrm{Ong}^{14}$ observed berried mud crabs of $12 \mathrm{~cm}$ in carapace length. In the present study, berried females observed were around $9.8-13.0 \mathrm{~cm}$ ln carapace length. 


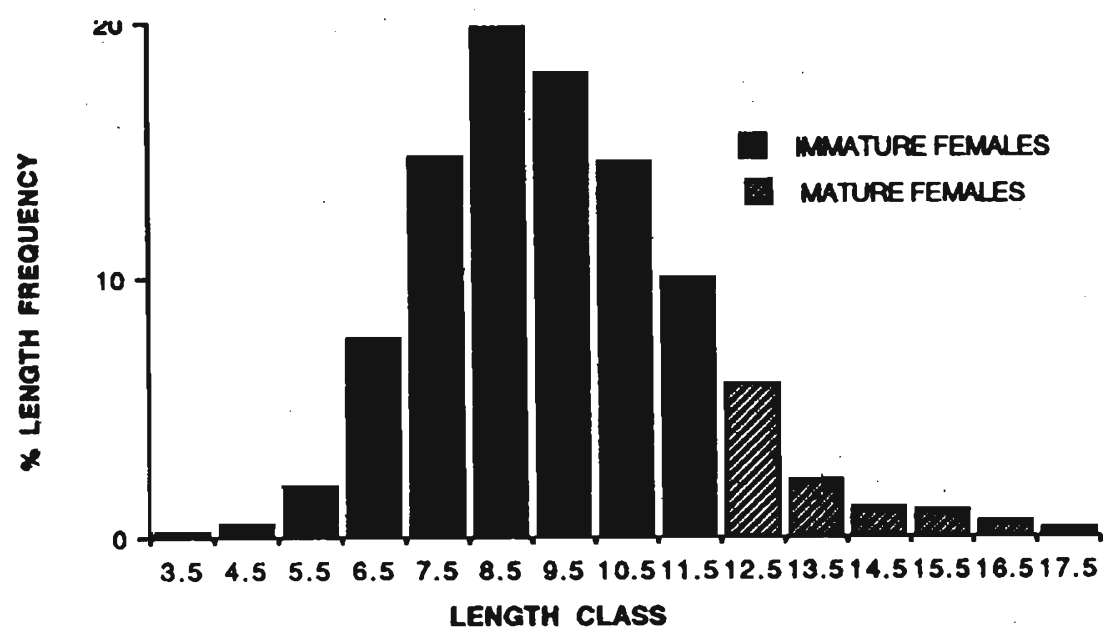

Figure 5: Percentage length frequency of female Scylla serrata Indicating the percentage of immature females in the commercial catch. $(n=17,535$.)

The pre-spawning fecundity of Scylla serrata in the Negombo estuary was estimated to be around $1.76-3.5$ million and the post spawning fecundity was around $1.28-1.84$ million. The size range of females used to estimate the fecundity was $9.8-13.8 \mathrm{~cm}$ width range. Similar estimates were reported from Philippines. Arriola ${ }^{5}$ estimated fecundity of Scylla serrata as 2.0 million eggs. Varikul ${ }^{4}$ et al. in Thailand estimated the fecundity in the same range (1-3 million ). However, all these estiamtes were with respect to post-spawning fecundity.

The ova mature at the size of $240-320 \mu \mathrm{m}$ in diameter and consist of 3 batches indicating partial spawning behaviour. This agrees with the observations of $\mathrm{Ong}^{14}$ who reported Scylla serrata as a multiple spawner which is able to extrude three batches of eggs without mating between ovulations.

Based on the occurrence of spawning females two seasons have been identified as spawning periods; April and August, which is confirmed by the presence of spent females in subsequent months May and September. Two spawning seasons per year have also been reported by Arriola in Philippines (May and September). Brick ${ }^{15}$ in Hawaii (May and October) and Le Reste ${ }^{16}$ in Madagascar (April/May and June/July). Pillay and Nair ${ }^{17}$ observed only one month of spawning (January) by Scylla serrata in Southwest coast of India. Others have observed single season of longer durations; Heasman $^{3}$ in Queensland (April-August), Estampador ${ }^{13}$ in Illoilo (August November) and Varikul ${ }^{4}$ in Thailand (July-December). Pillary and Nair ${ }^{17}$ have also 
reported that breeding of Scylla serrata occurs throughout the year. The uneven sex ratio in 1986 and 1987 may be connected with survival patteren of juveniles which were most abundant in June. This uneven distribution of males and females differs from the finding in other parts of the world where the sex was always reported to be even. ${ }^{6,3,8} \mathrm{It}$ could be due to a stronger year-class in a particular year, which repeat at regular intervals.

The percentage of immature females in the fish landings is extreamly high indicating growth overfishing. Further, there is evidence for overexploitation of the crab resources in the negombo estuary. ${ }^{18}$ There are regulations in other countries regarding the size of crabs captivable for marketing. ${ }^{19,20}$ Thus it appears appropriate and timely to impose laws in Sri Lanka to prevent capturing immature crabs to have a sustainable fishery.

\section{Acknowledgement}

The authors thank the National Aquatic Resources Agency and Natural Resources, Energy and Science Authority of Sri Lanka Grant No. RG/85/B/5 for financial support and N.N.E. Cooray, R.P.K. Tissa and P. G. Gunasinghe for field assistance. This study formed a part of the study for M.Phill. Degree of S.C. Jayamanna. In 1991 this investigation won a national merit award from NARESA.

\section{References}

1. Duplessis A. (1971). A preliminary investigation into the morphological characteristics, feeding, growth, reproduction and larval rearing of Scylla serrata Forskal (Decapoda: Portunidae) held in captivity. (unpublished.) Fisheries Development Corporation, South Africa.

2. Lavina Alice F. (1977). Courtship and mating behaviour of Scylla serrata in captivity. South East Asian Fisheries Development Centre (SEATDEC) Quarterly Research Report 2:9-11.

3. Heasman M.P. (1980). Aspects of the general biology and fishery of the mud crab Scylla serrata (Forskal) in Moreton Bay. (unpublished). Ph.D Thesis, Dept. of Zoology, University of Quecnsland, Brisbane, Australia.

4. Varikul V.S., Phumiphol S. \& Hongopromyart M. (1970). Preliminary experiment on pond rearing and some biological studies of Scylla serrata (Forskal). Symposium on Indo-Pasific Fishery Congress-C70 49, $14^{\text {th }}$ Session, Bangkok.

5. Arriola F.J. (1940). A preliminary study of the life history of Scylla serrata (Forskal). Philippine Joumal of Science 73 (4):437 - 454. 
6. Hill B.J. (1975). Abundance, breeding and growth of the crab Scylla serrata (Forskal) in two South African estuaries Marine Biology 32 : 119 -126.

7. Ragneker P.V. \& Deshmukh R.D. (1968). Effect of eyestalk removal on the ovarian growth of the marine crab Scylla serrata (Forskal). Joumal of Animal Morphology and Physiology, Baroda 15 : 116 - 126.

8. Williams M.J. \& Hill B.J. (1982). Factors influencing pot catches and population estimates of the Protunid crab Scylla serrata. Marine Biology 71 : 187 - 192.

9. Raphael Y.I. (1970). A preliminary report on the brackish culture of Scylla serrate (Forakal) in Ceylon. Symposium on Indo-Pacific Fishery Congress-C70 21, $14^{\text {th }}$ Session. Bangkok.

10. Arudpragasam K. D. (1967). Distribution and variation in form of the Ciripede octalasmis Cor in relation to the respiratory current of its host Scylla serrata. Ceylon Journal of Science 27(1-2) : 105 -115.

11. Bigford T. E. (1979). Synopsis of biological data on the rock crab, Cancer irroratus Say. FAO synopsis No 123 NOAA Technical Report NMFS Circular 426 Rockville.

12. Escritor G. L. (1970). A report on experiments in the culture of the mud crab, Scylla Serrata. Symposium on Indo-Pacific Fishery Congress-C $7046,14^{\text {th }}$ session, Bangkok.

13. Estampador E.P. (1949). Scylla Serrata (Crustacea: Portunidae). Comparative study on spermatogenesis and orgernesis. Philippine Journal of Science 78(3): 301-353.

14. Ong Kah Sin (1965). The early developmental stages of Scylla serrata Forskal (Crustacea:.Portunidae) reared in the laboratory. Indo-Pacific Fisheries Congress Proceeding II $135-146$.

15. Brick R.W. (1974). Effects of water quality antibiotics, phytoplankton and food survival of larvae of Scylla serrata (Crustaca : Portunidae). Aquaculture 3(3): $231-244$.

16. Le Reste L., L. Ramelson A. (1976). Etat de nos connaissances sur le crabe de vase Scylla serrata Forskel a Madagaskar. Paris, Office de la Recherche Scientificque et Technique Outre Mer. pp. 32.

17. Pillai K.K. \& Nair N.B. (1968). Observations on the reproductive cycles of some crabs from the south west coast of India. Joumal of Marine Biology, Assam India $10: 1-2$. 
18. Jayamanna S.C. (1992). Bionomics of the mud crab Scylla serrata. pp. 204. M.Phil. Thesis, Unversity of Sri Jayewardenepura, Nugegoda.

19. Hill B.J. (1982). The Queensland mud crab Fishery: Queensland Fisheries Information Series F1 8201, pp. 54.

20. Ladra D.F. (1991). Trade and marketing of mud crabs in the Philippines. Seminar for the "Culture and trade of Mud crab in the BOBP region", Surat Thani, Thailand. 